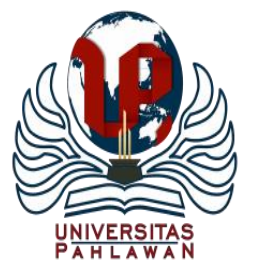

Jurnal Basicedu Volume 4 Nomor 4 Tahun 2020 Halaman 1066-1074

JURNAL BASICEDU

Research \& Learning in Elementary Education

https://jbasic.org/index.php/basicedu

\title{
Pengaruh Model Pembelajaran Picture And Picture Ditinjau Dari Kemampuan Berpikir Kritis Siswa Sekolah Dasar
}

\author{
Regita Kusuma Dewi ${ }^{1}$, Krisma Widi Wardani ${ }^{2}$ \\ Universitas Kristen Satya Wacana, Jawa Tengah, Indonesia ${ }^{1,2}$ \\ E-mail : 292016158@ student.uksw.edu ${ }^{1}$ Krisma.uksw@gmail.com ${ }^{2}$
}

\begin{abstract}
Abstrak
Penelitian ini bertujuan untuk mengetahui pengaruh kemampuan berpikir kritis kelas 5 SD Negeri 5 Kedungjati sebelum dan setelah menggunakan model pembelajaran Picture And Picture. Penelitian ini dilakukan tepat sebelum masa-masa work from home awal pandemi COVID-19, sehingga penelitian ini terbatas pada Pre-Eksperimental dengan tipe One Group Pre-test-Post-test Design. Pengumpulan data penelitian ini yaitu dengan instrumen tes berupa soal uraian yang diberikan pada awal dan akhir pembelajaran. Analisis data dilakukan berdasarkan data kuantitatif yaitu dengan menghitung rata-rata nilai pre-test-post-test, melakukan uji normalitas, uji homogenitas, dan uji one sample T-test untuk menguji apakah rata-rata nilai pre test dan post test berbeda secara signifikan dengan teknik one samples T-test dengan bantuan SPSS 23. Hasil penelitian: 1) kemampuan berpikir kritis siswa sebelum menggunakan model pembelajaran Picture And Picture nilai rata-rata sebesar 67,73. 2) kemampuan berpikir kritis pada siswa setelah menggunakan model pembelajaran Picture And Picture nilai rata-rata sebesar 85,73. 3). Hasil analisis data one sample T-test menggunakan teknik one sample T-test diperoleh hasil t hitung $52,428>$ tabel 1,713 dan nilai signifikansi $<0,05(0,000<0,05)$. Maka dapat disimpulkan bahwa terdapat pengaruh kemampuan berpikir kritis pada siswa kelas 5 SD Negeri 5 Kedungjati dengan menggunakan model pembelajaran Picture and Picture.
\end{abstract}

Kata kunci: model pembelajaran Picture and Picture; kemampuan berpikir kritis

\begin{abstract}
The study aims to know the impact of the critical thinking skills of 5th grade students of Elementary School 5 Kedungjati before and after using the Picture and Picture learning model. This study was done just before the days of work from home of early stages covid-19, so it was limited to pre-experimental with a type one group preprogrammed post-test design. This research data collection with a test instrument consists of descriptions given at the beginning and end of learning. The data analysis is based on the quantitative data by calculating the average value of pre-test post-test, conducting normality tests, homogenity tests, and testing One Sample of T-test samples to test whether the pre-test value and post tests differs significantly from the one test-test using SPSS 23. Research: 1) a student's critical thinking skills before using a Picture and Picture leraning model is 67,73. 2) Critical thinking ability in students after using using a Picture and Picture leraning model is 85,73. 3) the results of the analysis of one sample T-test data using the one sample test technique specimen obtained from $t$ count $52.428>t$ table 1.713 and ithe significance value $<0.05(0,000<0.05)$. Then it may be concluded that there is a critical effect of thinking skills in the 5th grade students of Elementary School 5 Kedungjati using the Picture and Picture learning model.
\end{abstract}

Keywords: Picture and Picture learning model; critical thinking skills

Copyright (c) 2020 Regita Kusuma Dewi, Krisma Widi Wardani

\begin{tabular}{l}
\hline$\triangle$ Corresponding author \\
Address : Universitas Kristen Satya Wacana \\
Email $\quad:$ 92016158@student.uksw.edu \\
Phone $\quad:-$ \\
DOI: https://doi.org/10.31004/basicedu.v4i4.511
\end{tabular}


1067 Pengaruh Model Pembelajaran Picture And Picture Ditinjau Dari Kemampuan Berpikir Kritis Siswa Kelas 5 SD Negeri 5 Kedungjati - Regita Kusuma Dewi, Krisma Widi Wardani

DOI: https://doi.org/10.31004/basicedu.v4i4.511

\section{PENDAHULUAN}

Pendidikan adalah bagian terpenting yang tidak bisa ditinggalkan. Pendidikan berfungsi untuk mencerdaskan, mengembangkan kepribadian manusia dan budi pekerti serta bermartabat. Pendidikan melalui pembelajaran di sekolah memiliki pengaruh besar pada proses tumbuh kembang dan potensi yang dimiliki siswa, sehingga berakibat menjadikan siswa insan yang beriman, bertakwa pada Tuhan Yang Maha Esa, berakhlak mulia, sehat, berilmu, cekatan, kreatif, berdikari dan sebagai masyarakat negara demokratis yang melaksanakan bertanggungjawab.

Di lain pihak, guru berperan penting dalam meningkatkan kualitas pendidikan yang bermutu. Guru tidak lagi sekedar penyaji informasi, melainkan guru juga harus mampu menjadi fasilitator, motivator dan pembimbing yang banyak memberikan kesempatan kepada siswa untuk mengolah secara mandiri informasi yang telah diterima (Sofyan, 2013:30). Dengan demikian, guru juga harus senantiasa meningkatkan ilmu pengetahuan dan teknologi sehingga mampu menghadapi berbagai permasalahan dalam dunia pendidikan. Proses Pembelajaran pada satuan pendidikan menurut Standar Nasional Pendidikan (Permendikbud No. 32 tahun 2013) diselenggarakan secara interaktif, inspiratif, menyenangkan, menantang, memotivasi Peserta Didik untuk berpartisipasi aktif, serta memberikan ruang yang cukup bagi prakarsa, kreativitas, dan kemandirian sesuai dengan bakat, minat, dan perkembangan fisik serta psikologis peserta didik.
Perkembangan teknologi pada masa ini sebagaimana diatur dalam Permendikbud No.22 Tahun 2016 tentang Standar Proses mengharuskan guru menghadapi banyak perubahan dan pembaharuan. Perubahan itu tidak sekedar perubahan struktur dan isi kurikulum atau pembelajaran, tetapi perubahan yang menuntut strategi pembelajaran terutama metode pembelajaran yang berpusat pada guru (teacher centered approaches) yang berubah menjadi pembelajaran yang berpusat pada siswa (studentcentered). Pembelajaran yang berfokus pada guru pengajar menurunkan strategi pembelajaran langsung (direct instruction), pembelajaran yang bersifat deduksi atau pembelajaran ekspositori. Sedangkan pembelajaran yang berpusat pada siswa meningkatkan semangat belajar, motivasi, minat, kreativitas dan inisiatif. Hal ini didukung penelitian yang dilakukan oleh (Susanti dan Yusron, 2020: 10) dengan hasil akhir siswa menjadi berkembang lebih aktif, inisiatif, memahami konsep, mampu memecahkan masalah, dan berani mengungkapkan pendapat. Dengan demikian guru memiliki peran penting untuk merancang dan menjalankan pembelajaran sesuai kurikulum 2013 dengan menerapkan pembelajaran tematik terpadu, sehingga siswa dapat secara aktif mengikuti sampai akhir pembelajaran.

Pembelajaran tematik terpadu merupakan strategi pembelajaran yang bermula dari satu tema yang dielaborasikan dari berbagai muatan pelajaran. Pembelajaran tematik merangsang siswa untuk ikut serta secara aktif dalam pelajaran, sehingga dapat menstimulus kemampuan berpikir siswa untuk memecahkan masalah. Keterampilan 
1068 Pengaruh Model Pembelajaran Picture And Picture Ditinjau Dari Kemampuan Berpikir Kritis Siswa Kelas 5 SD Negeri 5 Kedungjati - Regita Kusuma Dewi, Krisma Widi Wardani

DOI: https://doi.org/10.31004/basicedu.v4i4.511

berfikir siswa merupakan aktivitas berfikir yang berkaitan langsung dengan kondisi mental dan memiliki tujuan untuk membuat siswa dapat merumuskan pengertian, mensintesis, dan menarik kesimpulan (Sardiman, 2016:72). Di lain pandangan, berpikir kritis adalah kegiatan yang menunjukkan keaktifan siswa dengan menganalisis ide atau gagasan secara spesifik, kemudian secara tajam dibedakan, dipilih, lalu mengidentifikasi dan mengkaji ke dalam penemuan yang sempurna (Wijaya, 2010:72). Lebih mendalam keterampilan berpikir menyatakan manusia berpikir untuk menemukan pemahaman atau pengertian yang dikehendakinya (Santrock, 2011:357). Berpikir kritis adalah tindakan mengelola dan mengubah informasi dalam ingatan. Kemampuan berpikir kritis perlu ditingkatkan dengan alasan bahwa kemampuan berpikir kritis tidak hanya sematamata di sekolah saja melainkan akan sangat diperlukan juga di dalam kehidupan sehari-hari siswa (Suprijono, 2012:46). Telah ada berbagai macam model-model pembelajaran yang cukup mendukung perkembangan ketrampilan berpikir kritis bagi siswa.

Model pembelajaran ialah suatu pola yang diperuntukan dalam menyusun kurikulum belajar, membuat materi dan memberi arahan kepada guru kelas. Model pembelajaran Picture and Picture adalah model pembelajaran yang titik fokus siswanya terletak pada gambar yang diurutkan menjadi urutan yang dapat diterima oleh kenyataan, model pembelajaran ini mengembangkan interaksi antar siswa dengan saling mengasah pikiran, silih asih dan silih asuh (Zaenal, 2014:18). Model Picture and Picture (PAP) adalah metode belajar yang menggunakan gambar, kemudian dipasangkan atau diurutkan menjadi suatu urutan cerita yang logis. Siswa yang terlebih dulu selesai akan mendapat poin. Model pembelajaran ini memiliki ciri aktif, inovatif, kreatif dan menyenangkan (Hamdani, 2011:89). Lebih lengkap Istarani, 2011:7 menyebutkan pembelajaran Picture and Picture yaitu pembelajaran yang berisikan kegiatan sebagai berikut: 1) guru menyampaikan kompetensi yang ingin dicapai, 2) menyajikan materi sebagai pengantar awal pembelajaran, 3) guru memperlihatkan gambar-gambar secara acak yang berkaitan dengan materi, 4) guru menunjuk siswa secara bergantian mengurutkan gambar dan memasangkannya hingga menjadi urutan yang logis, 5) guru menanyakan alasan urutan gambar, 6) dari alasan urutan gambar, guru menanamkan konsep sesuai dengan kompetensi yang ingin dicapai, 7) siswa diajak untuk menyimpulkan materi yang sudah diterima.

(Mantira, Z. J., Syaiful, M., \& Arif, 2017:8) telah melakukan tentang pengaruh model pembelajaran Picture and Picture terhadap kemampuan berfikir kritis sejarah siswa. Hasil penelitian menunjukkan bahwa model pembelajaran Picture and Picture lebih. Hal ini bisa dilihat dari adanya pengaruh positif yang cukup berarti yaitu 0,49 dan signifikan yaitu 18,32 dari pengaruh model pembelajaran Picture and Picture terhadap kemampuan berpikir kritis siswa. Penelitian lain dilakukan oleh (Marhamah, 2018) mengenai penerapan pendekatan lingkungan dengan model Picture and Picture terhadap kemampuan berpikir kritis siswa pada pembelajaran IPA Kelas V SDN Alurmas Aceh Selatan. Hasil penelitian menunjukkan bahwa nilai 

Kelas 5 SD Negeri 5 Kedungjati - Regita Kusuma Dewi, Krisma Widi Wardani

DOI: https://doi.org/10.31004/basicedu.v4i4.511

uji-t (t-test) pada taraf signifikasi $\propto=0,05$ dengan derajat kebebasan $(\mathrm{dk}) 17$, diperoleh $\mathrm{t}$ hitung $=1,70$ dan untuk ttabel $=1,74$. Dengan kriteria pengujian yaitu thitung $>$ ttabel yaitu1,70 $\leq 1,74$, ini menunjukkan bahwa $\mathrm{H}_{\mathrm{a}}$ ditolak dan $\mathrm{H}_{\mathrm{o}}$ diterima. Maka dapat disimpulkan bahwa model pembelajaran Picture and Picture mampu menumbuhkan kemampuan berpikir kritis siswa.

Berdasarkan latar belakang di atas dan mendukung penelitian sebelumnya mengenai model pembelajaran Picture and Picture. Banyaknya model pembelajaran baru dan bervariasi, menjadikan pertanyaan, apakah model pembelajaran yang popular pada masa kurikulum KBK apakah memiliki pengaruh dalam meningkatkan ketrampilan berpikirkritis.

Peneliti bertujuan untuk melakukan penelitian di kelas 5 SD Negeri 5 Kedungjati dengan menggunakan jenis penelitian eksperimen dengan metode pre-eksperimental. SD Negeri 5 Kedungjati sebagai kelompok perlakuan tunggal artinya hanya ada satu kelompok perlakuan dan tidak ada kelompok pembanding. Pemilihan SD sebagai tempat penelitian disebabkan karena memiliki latar belakang yaitu menurunnya tingkat pemahaman siswa dan kesulitan dalam menyelesaikan masalah dikarenakan tingkat berpikir kritis yang sangat rendah. Maka peneliti bermaksud melakukan penelitian tentang "Efektifitas Penerapan Model Pembelajaran Picture and Picture Ditinjau dari Kemampuan Berpikir Kritis Siswa Kelas 5 SD Negeri 5 Kedungjati”.

\section{METODE}

Penelitian ini menggunakan jenis penelitian eksperimen, metode penelitian pre-eksperimental design dengan tipe one-group pre-test-post-test design. Menurut (Sugiono, 2014:109) metode eksperimen dengan design metode preekperimental tipe one-group pe-test-post-test design merupakan metode eksperimen yang telah dirancang hanya untuk atu kelompok atau hanya satu kelas yang diberikan pra dan pasca uji. Rancangan one-group pe-test-post-test design ini, diberlakukan terhadap satu kelompok saja tanpa adanya kelompok pembanding. Tujuan penelitian ini adalah untuk mengetahui pengaruh kemampuan berpikir kritis pada siswa kelas 5 SD Negeri 5 Kedungjati sebelum dan setelah menggunakan model pembelajaran Picture and Picture. Berikut ini desain metode penelitian pre-eksperimental dengan tipe one-group pre-test-post-test design menurut (Sugiyono, 2013:109).

Tabel 1. One-group Pre-test-Post-test Design

\section{$\mathrm{O}_{1} \mathrm{X} \mathrm{O}_{2}$}

Keterangan :

$\mathrm{X}=$ Perlakuan (model pembelajaran Picture and Picture)

$\mathrm{O}_{1}=$ Nilai Pre-test

$\mathrm{O}_{2}=$ Nilai Post-test

Populasi menurut (Darmadi, 2013:48) merupakan wilayah generalisasi yang terdiri atas objek/subjek yang mempunyai ciri-ciri mendasar untuk dipelajari, kemudian ditarik kesimpulan dan dijadikan sumber data dalam penelitian. Populasi dalam penelitian ini adalah seluruh siswa kelas 5 
1070 Pengaruh Model Pembelajaran Picture And Picture Ditinjau Dari Kemampuan Berpikir Kritis Siswa Kelas 5 SD Negeri 5 Kedungjati - Regita Kusuma Dewi, Krisma Widi Wardani

DOI: https://doi.org/10.31004/basicedu.v4i4.511

SD Negeri 5 Kedungjati. Subjek penelitian ini adalah siswa kelas 5 SD Negeri 5 Kedungjati berjumlah 23 siswa. Sampel menurut (Gay, L. R. Mills, G. E. Airasian, 2012) adalah bagian dari jumlah dan karakteristik yang dimiliki oleh populasi dari sampel yang diambil. Peneliti menetapkan sejumlah 23 siswa sebagai sampel penelitian ini yang terdiri dari siswa kelas 5 SD Negeri 5 Kedungjati. Teknik pengumpulan data yang digunakan dalam penelitian ini adalah teknik tes yang berjumlah 10 soal uraian. Sedangkan teknik analisis data yaitu uji normalitas, uji homogenitas, dan uji one sample T-test menggunakan teknik one sample test dengan bantuan SPSS 23.

\section{HASIL DAN PEMBAHASAN}

Dalam penelitian ini untuk mengetahui kemampuan berpikir kritis siswa data diperoleh dengan melakukan penilaian pre-test dan post-test melalui pemberian soal uraian sebanyak 10 butir. Test dilakukan hanya satu kelas sebagai subjek penelitian atau tidak ada kelas pembanding yaitu kelas 5 SD Negeri 5 Kedungjati yang berjumlah 23 siswa melalui pembelajaran tematik yaitu tema 8 Lingkungan sehat dan subtema 1 Manusia dan Lingkungan semester II tahun Pelajaran 2019/2020. Penelitian ini dilaksanakan dalam tiga tahap yaitu 1) memberikan tes awal (pre-test) sebelum memulai kegiatan pembelajaran, 2) melaksanakan pembelajaran dengan menggunakan model pembelajaran Picture and Picture, 3) memberikan tes akhir (post-test) setelah kegiatan pembelajaran. Adapun hasil perhitungan rata-rata nilai pre-test dan post-test dapat dilihat pada tabel 2 di bawah ini:

Tabel 2. Rata-rata Nilai pre-test dan post-test

\begin{tabular}{ll} 
Tes Uraian & Rata-rata \\
\hline Pre-test & 67,73 \\
Post-test & 85,73 \\
\hline
\end{tabular}

Berdasarkan hasil rata-rata nilai pre-test dan post-test terdapat peningkatan pencapaian ratarata nilai kemampuan berpikir kritis degan menggunakan model pembelajaran Picture and Picture. Hal ini dapat dilihat dari rata-rata nilai pre-test siswa sebelum menggunakan model pembelajaran Picture and picture sebesar 67,73. Kemudian rata-rata nilai post-testsiswa setelah menggunakan model pembelajaran Picture and Picture menjadi 80,17.

Selanjutnya peneliti melakukan uji normalitasdan uji homogenitas dari data hasil pretest dan post-test dengan bantuan SPSS 23. Uji normalitas menurut (Ghozali, 2016:154) dilakukan untuk mengetahui apakah model regresi variabel independen dan variabel dependen mempunyai distribusi normal atau tidak. Data dapat dikatakan berdistribusi normal apabila nilai signifikansi > 0,05 sedangkan signifikansi $<0,05$ maka data tersebut berdistribusi tidak normal. Uji normalitas dapat dilihat pada tabel 3 .

Berdasarkan hasil uji normalitas pada data pre-test menunjukkan nilai signifikansi 0,200 dan post-test menunjukkan nilai signifikansi 0,068 pada Kolmogorov-Smirnov. Sedangkan pada Shapiro-Wilk data pre-test menunjukkan nilai signifikansi 0,068 dan data post-test menunjukkan nilai signifikansi 0,068 . Sehingga data yang 
1071 Pengaruh Model Pembelajaran Picture And Picture Ditinjau Dari Kemampuan Berpikir Kritis Siswa Kelas 5 SD Negeri 5 Kedungjati - Regita Kusuma Dewi, Krisma Widi Wardani

DOI: https://doi.org/10.31004/basicedu.v4i4.511

diperoleh lebih besar dari signifikansi >0,05. Maka dapat disimpulkan bahwa data penelitian berdistribusi normal dan memenuhi syarat untuk dilakukan analisis parametrik dan data penelitian.

Setelah dilakukan uji normalitas, langka selanjutnya melakukan uji homogenitas dengan bantuan SPSS 23 menggunakan uji Levene. Uji homogenitas menurut (Putri et al, 2018:11) berfungsi untuk mencari kelompok data sampel yang dapat dikatakan homogen. Uji homogenitas juga digunakan sebagai persyaratan untuk bisa dilakukan analisis lebih lanjut. Kriteria uji homogenitas adalah jika data dapat dinyatakan homogen apabila nilai signifikansi menunjukkan $>0,05$, dan tidak dikatakan homogen jika nilai signifikansi $<0,05$. Uji homogenitas dapat dilihat pada tabel 4 .
Berdasarkan hasil uji homogenitas terbukti lebih besar dari signifikansi >0,05 yaitu menunjukkan nilai signifikansi sebesar 1,000. Maka data penelitian dapat dinyatakan homogen.

Setelah melakukan uji normalitas dan uji homogenitas dapat disimpulkan bahwa data penelitian berdistribusi normal dan homogen. Selanjutnya akan dilakukan uji hipotesis kemampuan berpikir kritis siswa sebelum dan setelah menggunakan model pembelajaran Picture and Picture dengan menggunakan uji one sample T-test melalui teknik one sample test dengan bantuan SPSS 23. Pengambilan keputusan dalam uji hipotesis yaitu Sig. (2-tailed) $<0,05$ maka $\mathrm{H}_{\mathrm{o}}$ diterima dan $\mathrm{H}_{\mathrm{a}}$ ditolak.

Tabel 3. Uji Normalitas

\begin{tabular}{|c|c|c|c|c|c|c|c|}
\hline \multirow{2}{*}{$\begin{array}{c}\text { Kemampuan Berpikir } \\
\text { Kritis }\end{array}$} & \multirow[t]{2}{*}{ Kelas } & \multicolumn{3}{|c|}{ Kolmogorov-Smirnova } & \multicolumn{3}{|c|}{ Shapirov-Wilk } \\
\hline & & Statistic & Df & Sig & Statistic & Df & Sig \\
\hline & Pre-test & ,129 & 23 & ,200 & ,920 & 23 & ,068 \\
\hline & Post-test & ,129 & 23 & ,200 & ,920 & 23 & ,068 \\
\hline
\end{tabular}

Tabel 4. Uji Homogenitas

\begin{tabular}{|c|c|c|c|c|}
\hline $\begin{array}{c}\text { Kemampuan } \\
\text { Berpikir Kritis }\end{array}$ & $\begin{array}{c}\text { Levene } \\
\text { Statistiic }\end{array}$ & Df1 & Df2 & Sig. \\
\cline { 2 - 5 } &, 000 & 1 & 44 & 1,000 \\
\hline
\end{tabular}

Tabel 5. Uji One Sample Test

\begin{tabular}{|c|c|c|c|c|c|c|}
\hline \multirow{2}{*}{$\begin{array}{c}\text { Kemampuan } \\
\text { Berpikir Kritis }\end{array}$} & \multicolumn{3}{|c|}{ Test Value = 100 } \\
\cline { 2 - 7 } & $\mathrm{t}$ & $\mathrm{df}$ & Sig. (2-tailed) & Mean Difference & \multicolumn{2}{|c|}{$\begin{array}{c}\text { 95\% Confidence Interval of the } \\
\text { Difference }\end{array}$} \\
\cline { 2 - 7 } & 52,428 & 45 & \multirow{2}{*}{000} & 76,739 & Lower & Upper \\
\cline { 5 - 7 } & & & & & 73,79 & 79,69 \\
\hline
\end{tabular}

Hipotesis yang diuji dalam penelitian ini, yaitu:
1. $\mathrm{H}_{\mathrm{o}}$ : Tidak terdapat pengaruh kemampuan berpikir kritis pada pembelajaran tematik 
1072 Pengaruh Model Pembelajaran Picture And Picture Ditinjau Dari Kemampuan Berpikir Kritis Siswa Kelas 5 SD Negeri 5 Kedungjati - Regita Kusuma Dewi, Krisma Widi Wardani

DOI: https://doi.org/10.31004/basicedu.v4i4.511

siswa kelas 5 SD Negeri 5 Kedungjati Tahun Ajaran 2019/2020 dengan menerapkan model pembelajaran Picture and Picture.

2. $\mathrm{H}_{\mathrm{a}}$ :Terdapat pengaruh kemampuan berpikir kritis pada pembelajaran tematik siswa kelas 5 SD Negeri 5 Kedungjati Tahun Ajaran 2019/2020 dengan menerapkan model pembelajaran Picture and Picture.

Berdasarkan hasil uji one sample T-test menunjukkan bahwa terdapat pengaruh menggunakan model pembelajaran Picture and Picture yang diberikan kelas pre-eksperimen. Hal ini dapat diketahui hasil t hitung 52,428. Hal ini menunjukkan bahwa terdapat pengaruh kemampuan berpikir kritis pada siswa kelas $5 \mathrm{SD}$ Negeri 5 Kedungjati Tahun Ajaran 2019/2020 dengan menerapkan model pembelajaran Picture and Picture.

Penelitian ini didukung oleh (Marhamah, 2018) yang telah melakukan penelitian tentang Penerapan Pendekatan Lingkungan dengan Model Picture and Picture terhadap Kemampun Berpikir Kritis Siswa pada Pembelajaran IPA Kelas V SDN Alurmas Aceh. Hasil penelitian menunjukkan bahwa terdapat peningkatan kemampuan berpikir kritis siswa melalui model Picture and Picture. Hal ini dapat dilihat dari nilai $\mathrm{t}$ hitung $1,70<\mathrm{t}$ tabel dan peningkatan terhadap nilai pre-test dan post-test yaitu sebesar 23,01.

Penelitian lain juga dilakukan oleh (Gitantri, 2012:39) telah melakukan penelitian Penerapan Pembelajaran Kooperatif Berbasis Contextual Teaching Learning Metode Picture and Picture untuk Meningkatkan Kemampuan Berpikir Kritis Siswa. Hasil penelitian menunjukkan bahwa terdapat peningkatan kemampuan berpikir kritis siswa melalui model Picture and Picture. Hal ini dapat dilihat dari peningkatan nilai rata-rata 71,46 , lalu menjadi 90,18.

Berdasarkan uraian diatas dapat diketahui bahwa 1) kemampuan berpikir kritis siswa sebelum menggunakan model pembelajaran Picture and Picture nilai rata-rata sebesar 67,73. 2) kemampuan berpikir kritis dan pembelajaran siswa setelah menggunakan model pembelajaran Picture and Picture nilai rata-rata sebesar 85,73. Hasil analisis data one sample T-test menggunakan teknik one sample test diperoleh hasil t hitung $52,428>t$ tabel 1,713 dan nilai signifikansi pada kolom Sig. (2- tailed), $<0,05(0,000<0,05)$. Hal ini menunjukkan bahwa terdapat pengaruh kemampuan berpikir kritis pada siswa kelas $5 \mathrm{SD}$ Negeri 5 Kedungjati Tahun Ajaran 2019/2020 dengan menggunakan model pembelajaran Picture and Picture.

\section{SIMPULAN}

Berdasarkan hasil rata-rata pre-test dan post-test terdapat peningkatan pencapaian rata-rata nilai kemampuan berpikir kritis dengan menggunakan model pembelajaran Picture and Picture. Hal ini dapat dilihat dari rata-rata pre-test siswa sebelum menggunakan model pembelajaranPicture and Picture sebesar 67,73. Kemudian rata-rata nilai post-test setelah menggunakan model pembelajaran Picture and Picture nilai rata-rata sebesar 85,73. Hal ini dibuktikan melalui hasil analisis data one sample T-test menggunakan teknik one sample test diperoleh hasil $\mathrm{t}$ hitung 52,428 $\mathrm{t}$ tabel 1,713 dan nilai signifikansi pada kolom Sig. (2- tailed), <0,05 $(0,000<0,05)$. Maka $\mathrm{H}_{\mathrm{a}}$ diterima dan $\mathrm{H}_{\mathrm{o}}$ ditolak. 
1073 Pengaruh Model Pembelajaran Picture And Picture Ditinjau Dari Kemampuan Berpikir Kritis Siswa Kelas 5 SD Negeri 5 Kedungjati - Regita Kusuma Dewi, Krisma Widi Wardani

DOI: https://doi.org/10.31004/basicedu.v4i4.511

dengan itu dapat disimpulkan bahwa $\mathrm{H}_{\mathrm{a}}$ menunjukkan jika terdapat pengaruh yang signifikan kemampuan berpikir kritis siswa setelah memberikan pre-test dan post-testmenggunakan model pembelajaran Picture and Picture.

Berdasarkan hasil penelitian yang telah dilakukan tentunya terdapat kekurangan dan kelebihan dalam menerapkan model pembelajaran Picture and Picture. Adapun kekurangan penerapan model pembelajaran Picture and Picture, yaitu sulitnya mendapatkan gambar yang berkualitas dengan materi yang diajarkan, sehingga harus membuat desain gambar sendiri. Sedangkan kelebihan menerapkan model pembelajaran Picture and Picture yaitu siswa lebih cepat menangkap materi ajar karena guru menunjukkan gambar-gambar sesuai materi yang dipelajari.

Peneliti menyarankan bagi para guru diharapkan dapat menggunakan model pembelajaran Picture and Picture, agar siswa terlibat aktif dan mampu meningkatkan kemampuan berpikir kritis dengan cara mengaitkan materi pembelajaran di kehidupan sehari-hari, menyelesaikan masalah yang berkaitan dengan kehidupan sehari hari menggunakan sebuah media gambar. Kemudian bagi Kepala Sekolah diharapkan dapat menjadi pertimbangan dalam pelaksanaan supervisi di SD Negeri 5 Kedungjati. Sedangkan bagi peneliti selanjutnya, diharapkan menjadi referensi memperoleh hasil yang lebih maksimal dalam melakukan penelitian dengan menggunakan model pembelajaran Picture and Picture terhadap kemampuan berpikir kritis siswa.

\section{DAFTAR PUSTAKA}

Darmadi, H. (2013). Metode Penelitian Pendidikan dan Sosial. Alfabeta.

Gay, L. R. Mills, G. E. Airasian, P. (2012). Educational research: competencies for analysis. Pearson Education.

Ghozali, I. (2016). Aplikasi Analisis Multivariate dengan Program IBM SPSS 23 . Edisi 8. Cetakan ke-8. Semarang: Badan Penerbit Universitas Diponegoro. 2011.

Gitantri, F. (2012). Penerapan Pembelajaran Kooperatif Berbasis Contextual Teaching Learning Metode Picture And Picture Untuk Meningkatkan Kemampuan Berpikir Kritis Siswa (Doctoral dissertation, Unnes).

Hamdani. (2011). Strategi Belajar Mengajar. Pustaka Setia.

Istarani. (2011). Model Pembelajaran Inovatif (Referensi Guru Dalam Menentukan Model Pembelajaran). Media Persada.

Mantira, Z. J., Syaiful, M., \& Arif, S. (2017). Pengaruh Model Pembelajaran Picture and Picture terhadap Kemampuan Berpikir Kritis Sejarah Siswa. PESAGI (Jurnal Pendidikan Dan Penelitian Sejarah), 5(3), 1-12.

Marhamah, N. (2018). Penerapan Pendekatan Lingkungan dengan Model Picture And Picture terhadap Kemampuan Berpikir Kritis Siswa pada Pembelajaran IPA di Kelas V SDN Alurmas Aceh Selatan (Doctoral dissertation, UIN Ar-Raniry Banda Aceh).

Putri, D. A., Suwatno, S., \& Sobandi, A. (2018). PENINGKATAN

KEMAMPUAN

BERPIKIR KRITIS SISWA MELALUI METODE PEMBELAJARAN TEAM GAMES TOURNAMENTS DAN TEAM ASSISTED INDIVIDUALIZATION. Jurnal MANAJERIAL.

https://doi.org/10.17509/manajerial.v17i1.97 39

Santrock, J. W. (2011). Perkembangan anak edisi 7 jilid 2. Terjemahan: Sarah Genis B) Jakarta: Erlangga.

Sardiman. (2016). Interaksi dan Motivasi Belajar Mengajar. In Jakarata: Raja Grafindo Persada.

Sofyan, A. (2013). Pengembangan \& Model Pembelajaran Dalam Kurikulum. 47.

Sugiono, P. . (2014). Metode penelitian pendidikan pendekatan kuantitatif.pdf. In Metode Penelitian Pendidikan Pendekatan Kuantitatif, Kualitatif Dan R\&D.

Sugiyono. (2013). Metode Penelitian Pendidikan 
1074 Pengaruh Model Pembelajaran Picture And Picture Ditinjau Dari Kemampuan Berpikir Kritis Siswa Kelas 5 SD Negeri 5 Kedungjati - Regita Kusuma Dewi, Krisma Widi Wardani

DOI: https://doi.org/10.31004/basicedu.v4i4.511

Pendekatan Kuantitaif, Kualitatif, dan R\&DSugiyono. 2013. "Metode Penelitian Pendidikan Pendekatan Kuantitaif, Kualitatif, dan R\&D." Metode Penelitian Pendidikan Pendekatan Kuantitaif, Kualitatif, dan R\&D. https://doi.org/10.1. In Metode Penelitian Pendidikan Pendekatan Kuantitaif, Kualitatif, dan $R \& D$. https://doi.org/10.1007/s13398-014-0173-7.2

Suprijono. (2012). Cooperative Learning. Pustaka Pelajar.

Susanti, S., \& Yusron Wikarya, M. P. (n.d.). PENGARUH PENDEKATAN STUDENT CENTERED APPROACH TERHADAP KEAKTIFAN DAN HASIL BELAJAR SENI RUPA DI SMPN 10 PADANG. Journal of Art Education.

Wijaya, C. (2010). Pendidikan Remedial: Sarana Pengembangan Mutu Sumber Daya Manusia. PT Remaja Rosdakarya.

Zaenal, A. (2014). Model-model Pembelajaran. Yrama Widya. 